\title{
Liquid Biofertilizer and Inorganic Nutrients Effect on Physiological, Quality Parameters and Productivity of Kharif Groundnut (Arachis hypogaea L.)
}

\author{
Neelam Singh, Ekta Joshi*, D.S. Sasode, R.S. Sikarwar and G.S. Rawat \\ Department of Agronomy, RVSKVV, College of Agriculture, Gwalior-474002, India
}

*Corresponding author

\begin{tabular}{|c|c|}
\hline & A B S T R A C T \\
\hline & \multirow{6}{*}{$\begin{array}{l}\text { Persistent nutrient depletion is posing a greater threat to the sustainable agriculture. } \\
\text { Therefore, it becomes imperative to explore the most effective combination of inorganic } \\
\text { fertilizers and liquid biofertilizers for sustaining the soil fertility and producing quality } \\
\text { products. Hence, a field trial was conducted during kharif } 2017 \text { at College of Agriculture, } \\
\text { Gwalior with a view to assess the effect of fertility levels and biofertilizers on quality and } \\
\text { physiological parameters of groundnut. Experiment laid out as split plot comprised } 12 \\
\text { treatment combinations replicated thrice in fixed plots having four fertility levels viz., } 25 \text {, } \\
50,75 \text { and } 100 \% \text { recommended rate of fertilizers as main plots and three bioformulations } \\
\text { viz., no bio-formulations }\left(\mathrm{B}_{1}\right) \text {, NPK liquid formulation }+\mathrm{Zn} \text { solubilizing bacteria }\left(\mathrm{B}_{2}\right) \text { and } \\
\text { bio-grow application }\left(\mathrm{B}_{3}\right) \text { as sub plots. Application of bioformulation as liquid NPK with } \\
\mathrm{Zn} \text { solublizing bacteria resulted in better physiological growth and highest kernel }(2114 \\
\mathrm{kg} / \mathrm{ha} \text { ) and haulm yield }(6676 \mathrm{~kg} / \mathrm{ha}) \text { of groundnut crop. Same treatment also resulted in } \\
\text { highest protein }(4.4 \mathrm{~kg} / \mathrm{ha}) \text { and oil yield }(6.7 \mathrm{~kg} / \mathrm{ha}) \text {. Application of } 100 \% \text { RDF with } \\
\text { bioformulation as NPK liquid formulation }+\mathrm{Zn} \text { solubilizing bacteria produced highest } \\
\mathrm{LAI} \text {, CGR, RGR values as well as protein and oil yield of groundnut followed by } 100 \% \\
\text { RDF with biogrow application. }\end{array}$} \\
\hline Keywords & \\
\hline $\begin{array}{l}\text { Liquid biofertilizer, } \\
\text { Quality, Groundnut, } \\
\text { Physiological } \\
\text { parameter, Inorganic } \\
\text { fertilizer }\end{array}$ & \\
\hline Article Info & \\
\hline $\begin{array}{l}\text { Accepted: } \\
\text { 06 August } 2018 \\
\text { Available Online: } \\
\text { 10 September } 2018\end{array}$ & \\
\hline & \\
\hline
\end{tabular}

\section{Introduction}

Groundnut, being an important source of edible oil, digestible protein and carbohydrates, has been given great attention due to its ample contribution to human nutrition. Due to constant decrement in soil fertility status, its production and productivity is low in the country. The deficiency of macro and micro nutrient in soil leads to poor quality produce (lower oil and protein content). Persistent nutrient depletion is posing a greater threat to the sustainable agriculture. Although, chemical fertilizers are playing crucial role but various constraints viz., short in supply, rising price and harm to the soil fertility and productivity increased the awareness to adopt a technology which can support developing sustainable, green and non-polluted agriculture.

Among different oilseed crops, groundnut occupies pre-dominant position in the state. But inadequate evidences are available on the 
combined use of biofertilizer and inorganic sources in Gird region of Madhya Pradesh. There is an urgent need for steeping use of major, secondary and micronutrients (Hegde and Sudhakarbabu, 2009) which can be overcome by the use of bio fertilizers. Hence, it becomes imperative to explore the most effective combination of inorganic fertilizers and biofertilizers for sustaining the soil fertility and producing quality products. The bio-fertilizers besides providing a good substrate for crop growth help to proliferate beneficial microbes in soil and also provide residual effect for subsequent crops. These inoculants aid in meeting nutrient demands of crops through proper nitrogen fixation by increasing nodulation and solubilisation of insoluble phosphorus and extend the nutrient absorption to inaccessible zones. In our present investigation multi strain biofertilizers are used which when applied alone or along with inorganic or organic source stimulate various morpho-physiological and quality traits in crop and it appears to be a good trail with regard to saving of chemical fertilizers and quality food production. Inoculation with bio-grow containing a pseudomonas, two bacilli and a soil yeast significantly increased grain and straw yield in paddy (Phan Thi Cong et al., 2011).

Though, biofertilizer helps to provide nutrients to crop but using it alone cannot give spectacular results. Thus, integrated use of both will be more beneficial and environment friendly. Considering the facts and views highlighted above, the present study was planned to study the effect of inorganic and bio-fertilizers application on quality and physiological parameters of kharif groundnut.

\section{Materials and Methods}

A field experiment was carried out at the research farm of Department of Agronomy, RVSKVV, College of Agriculture, Gwalior during kharif 2017. The soil was neutral in reaction ( $\mathrm{pH}$ 7.3) and has $0.37 \mathrm{dS} \mathrm{m} \mathrm{m}^{-1}$ electrical conductivity. The status of organic carbon $(0.56 \%)$ was medium whereas the soil has low initial $\mathrm{N}(208.7 \mathrm{~kg} / \mathrm{ha})$, medium $\mathrm{P}$ (13.1 kg/ha) and high K (268.8 kg /ha) contents. The recommended dose of NPK for groundnut is $20-60-20 \mathrm{~kg} / \mathrm{ha}$. The experiment had 12 treatments combinations, set in a split plot design with three replications in fixed plots. The main plot treatments consisted of using four fertility levels as 25, 50, 75 and $100 \%$ recommended rate of fertilizers with three bioformulation applications as no bioformulations, NPK liquid formulation $+\mathrm{Zn}$ solubilizing bacteria and bio-grow. The recommended rate of fertilizers were applied in full as basal dose through urea, single super phosphate and muriate of potash, respectively at the time of sowing. The gross plot size was $5.0 \mathrm{~m} \times 4.5 \mathrm{~m}$ and the seed of JGN3 cultivar of groundnut@100 kg/ha was sown on $6^{\text {th }}$ July 2017.

To prevent seed borne diseases, the kernels were treated with the fungicides Dithane M-45 @ 2g/kg seed, bavistin @ 1g/kg seed and with biofertilizers as per the treatments before sowing. A high incidence of thrips and bud necrosis virus was noticed which was controlled by treating the crop with an insecticide Dimethoate 30 EC @ 2 ml/litre water at 45 DAS. Chlorpyrifos @ 1.51 a.i./ha was incorporated in soil to control termite infestation before sowing and at 40 DAS. Imidacloprid (@1 ml/litre water)+ Mancozeb (@ $2 \mathrm{~g} /$ litre) at the time of disease occurrence were applied against fungal diseases as early blight, late blight and stem rot. Three irrigations were provided to groundnut and two hand weedings were done to control the weeds. Five plants in each plot were selected randomly for observations on quality and physiological parameters. Observations were made on leaf area index, crop growth rate ( $\mathrm{g}$ $/ \mathrm{m}^{2} /$ day), relative growth rate $(\mathrm{g} / \mathrm{g} /$ day) at 30 , 
60 and 90 DAS and quality parameters were analysed in groundnut kernels at harvest. Pods were sun dried up to $9 \%$ moisture level. Statistical analysis of the data was carried out using analysis of variance technique (Gomez and Gomez, 1984).

\section{Results and Discussion}

\section{Physiological parameters}

The effect of biofertilizer treatments on various physiological traits is shown in Table 1. The result revealed that LAI, CGR and RGR were significantly influenced with the application of bio formulations at all growth stages. Among different biofertilizer treatments, inoculation with liquid Bio-NPK + Bio- $\mathrm{Zn}\left(\mathrm{B}_{2}\right)$ and Bio-grow $\left(\mathrm{B}_{3}\right)$ formulations recorded significantly higher values of LAI, CGR and RGR at 30, 60 and 90 DAS compared to no bio formulation application. LAI significantly increased with the crop growth under the treatment but CGR and RGR, in the initial stages of development, were not influenced by the treatment but improved significantly in the later stage of crop growth at 60-90 DAS. The maximum values for all the physiological attributes were recorded with the application of liquid Bio$\mathrm{NPK}+\mathrm{Bio}-\mathrm{Zn}\left(\mathrm{B}_{2}\right)$ however it remained statistically at par with Bio-grow $\left(\mathrm{B}_{3}\right)$. It might be due to application of biofertilizers stimulated light interception by the crop which contributed towards the vegetative growth of crop plants leading to higher LAI values (Aduloju et al., 2009). Greater LAI further enhances crop growth resulting in higher yield. These findings are in line with earlier findings of Gorttapeh et al., (2000) and Dutta et al., (2012).

Similarly, all the aforesaid physiological parameters were significantly influenced under different fertility treatments. The treatment with $100 \%$ RDF resulted in maximum LAI, CGR and RGR at all growth stages. The balanced and optimum dose of NPK application had markedly improved overall growth of the crop is terms of DMA per plant by virtue of its impact on morphological and photosynthetic components (Table 1). A faster growth rate in terms of dry matter production as evidenced from higher CGR under the influence of balanced and higher level of fertilization which might have played a significant role in reducing competition for photosynthates and nutrients with other plants resulting in healthy plants. The increased availability of photosynthates might have enhanced number of flowers and their fertilization resulting in higher number of kernels per plant.

The increased trend of physiological traits might be due to the fact that at early stages applied nutrients might have been entirely used for vegetative growth that would have led to higher crop growth and hence higher crop growth rate and relative growth rate. This suggests greater availability of and metabolites for growth and development of reproductive structures (sink), which ultimately led to realization of higher productivity of individual plant. The findings are in close conformity with those reported by Afifi et al., (2011) and Vala et al., (2017).

\section{Quality parameters}

An appraisal of data shown in Table 2 revealed that inoculating seeds with bioformulations did not showed any significant effects on quality traits as moisture, sugar, oil and protein $\%$ and oil yield $(\mathrm{kg} / \mathrm{ha})$ in kernels but the effect was significant for protein yield. The treatments with liquid Bio-NPK+ Bio-Zn $\left(\mathrm{B}_{2}\right)$ recorded the maximum values for oil (31.2\%), oil yield $(4.4 \mathrm{~kg} / \mathrm{ha})$, protein $(47.7 \%)$, protein yield $(6.7 \mathrm{~kg} / \mathrm{ha})$ and sugar\% (5.5) except moisture percentage. This might be due to the fact that applying biofertilizers along 
with inorganic sources increased availability of nutrients timely which in turn accelerated crop growth and there by enhanced quality parameters of groundnut. This increase in oil content under bioformulation application can be assigned to the availability of all the essential nutrients due to its continuous mineralization. These results are in close agreement with the findings of Nadaf et al., (2013). Application of fertilizers had no significant effects on the aforesaid quality traits except oil and protein yield which were significantly influenced under fertilizer treatments. The treatment receiving 100\% $\mathrm{RDF}$ was at par with $75 \% \mathrm{RDF}$ and recorded maximum values for oil content $(31.1 \%)$, oil yield $(4.5 \mathrm{~kg} / \mathrm{ha})$, protein content $(47.8 \%)$, protein yield $(6.9 \mathrm{~kg} / \mathrm{ha})$ and sugar concentration (5.5\%) in groundnut kernels.

The values for moisture per cent were not influenced under all fertility treatments. Increase in protein content might be due to absorption of more nitrogen by groundnut crop through kernel which might have accumulated more nitrogen and consequently increased protein content. As nitrogen and phosphorus has no direct role in oil content but they were indirectly responsible for synthesis of essential metabolites which in turn increased oil content and oil yield (Mahasen et al., 2002). The increasing levels of RDF up to $100 \%$ significantly increased oil yield. Since, $\mathrm{N}$ content in plants manifests the protein content. Hence, increased availability of nitrogen increased protein content and thereby protein yield. These results are in line with the findings of More et al., (2002) and Singh et al., (2011).

\section{Seed and haulm yield}

Seed inoculation with liquid NPK formulation $+\mathrm{Zn}$ solubilizing bacteria produced the highest pod $(2114 \mathrm{~kg} / \mathrm{ha})$ and haulm yield $(2029 \mathrm{~kg} / \mathrm{ha})$ which was statistically at par with bio-grow and no bio formulation application (Table 3).

Table.1 Effect of nutrient management practices and bio formulations on physiological parameters of groundnut

\begin{tabular}{|c|c|c|c|c|c|c|c|}
\hline \multirow[t]{2}{*}{ Treatment } & \multicolumn{3}{|c|}{ LAI } & \multicolumn{2}{|c|}{ CGR (g/m²/day) } & \multicolumn{2}{|c|}{ RGR (g/g/day) } \\
\hline & $\begin{array}{l}30 \\
\text { DAS }\end{array}$ & 60 DAS & 90 DAS & $\begin{array}{l}\text { 30-60 } \\
\text { DAS }\end{array}$ & $\begin{array}{l}\text { 60-90 } \\
\text { DAS }\end{array}$ & $\begin{array}{l}\text { 30-60 } \\
\text { DAS }\end{array}$ & $\begin{array}{l}60-90 \\
\text { DAS }\end{array}$ \\
\hline \multicolumn{8}{|l|}{ Main Plots: Fertility levels } \\
\hline $\mathrm{F}_{1}: \mathbf{2 5} \% \mathrm{RDF}$ & 0.89 & 1.95 & 3.01 & 0.16 & 0.19 & 0.004 & 0.004 \\
\hline $\mathrm{F}_{2}: \mathbf{5 0 \%} \mathrm{RDF}$ & 0.97 & 2.03 & 3.09 & 0.18 & 0.34 & 0.005 & 0.006 \\
\hline$F_{3}: 75 \% R D F$ & 1.03 & 2.09 & 3.15 & 0.18 & 0.38 & 0.004 & 0.006 \\
\hline$F_{4}: 100 \%$ RDF & 1.05 & 2.10 & 3.17 & 0.28 & 0.49 & 0.006 & 0.007 \\
\hline S.Em \pm & 0.001 & 0.001 & 0.001 & 0.010 & 0.011 & 0.0002 & 0.0002 \\
\hline LSD $(P=0.05)$ & 0.005 & 0.003 & 0.002 & 0.034 & 0.038 & 0.0008 & 0.0007 \\
\hline \multicolumn{8}{|l|}{ Sub Plots: Bioformulations } \\
\hline $\mathrm{B}_{1}$ : No Bio-formulations & 0.96 & 2.02 & 3.08 & 0.19 & 0.29 & 0.005 & 0.005 \\
\hline $\begin{array}{l}\mathbf{B}_{2}: \text { NPK liquid formulation }+\mathrm{Zn} \\
\text { solubilizing bacteria }\end{array}$ & 1.01 & 2.07 & 3.13 & 0.21 & 0.40 & 0.005 & 0.006 \\
\hline B $_{3}$ : Bio-grow & 0.99 & 2.05 & 3.11 & 0.20 & 0.37 & 0.005 & 0.006 \\
\hline S.Em+ & 0.001 & 0.001 & 0.001 & 0.009 & 0.014 & 0.0002 & 0.0003 \\
\hline LSD $(P=0.05)$ & 0.003 & 0.003 & 0.003 & 0.027 & 0.042 & 0.0006 & 0.0008 \\
\hline \multicolumn{8}{|l|}{ Interaction } \\
\hline S.Em+ & 0.002 & 0.002 & 0.002 & 0.018 & 0.028 & 0.0004 & 0.0005 \\
\hline LSD $(P=0.05)$ & 0.005 & 0.006 & 0.006 & 0.054 & 0.084 & 0.0012 & 0.0015 \\
\hline
\end{tabular}


Table.2 Effect of nutrient management practices and bio formulations on Quality parameters of groundnut

\begin{tabular}{|c|c|c|c|c|c|c|}
\hline Treatment & $\begin{array}{c}\text { Moisture } \\
\%\end{array}$ & $\begin{array}{c}\text { Protein } \\
\%\end{array}$ & $\begin{array}{l}\text { Protein } \\
\text { (kg/ha) }\end{array}$ & Oil \% & $\begin{array}{c}\text { Oil } \\
\text { (kg/ha) }\end{array}$ & Sugar \% \\
\hline \multicolumn{7}{|l|}{ Main Plots: Fertility levels } \\
\hline$F_{1}: 25 \%$ RDF & 6.4 & 30.9 & 3.6 & 48.0 & 5.6 & 5.4 \\
\hline $\mathrm{F}_{2}: 50 \%$ RDF & 6.4 & 31.0 & 4.0 & 47.9 & 6.2 & 5.5 \\
\hline $\mathrm{F}_{3}: 75 \% \mathrm{RDF}$ & 6.4 & 31.1 & 4.4 & 47.8 & 6.7 & 5.5 \\
\hline $\mathrm{F}_{4}: 100 \% \mathrm{RDF}$ & 6.4 & 31.1 & 4.5 & 47.8 & 6.9 & 5.5 \\
\hline S.Em+ & 0.06 & 0.30 & 0.09 & 0.28 & 0.12 & 0.08 \\
\hline $\operatorname{LSD}(P=0.05)$ & 0.22 & 1.04 & 0.31 & 0.95 & 0.41 & 0.28 \\
\hline \multicolumn{7}{|l|}{ Sub Plots: Bioformulations } \\
\hline $\mathrm{B}_{1}$ : No Bio-formulations & 6.4 & 30.8 & 3.9 & 48.1 & 6.1 & 5.4 \\
\hline $\begin{array}{l}\mathbf{B}_{2}: \text { NPK liquid formulation + } \\
\text { Zn solubilizing bacteria }\end{array}$ & 6.4 & 31.2 & 4.4 & 47.7 & 6.7 & 5.5 \\
\hline B $_{3}$ : Bio-grow & 6.4 & 31.1 & 4.1 & 47.8 & 6.3 & 5.5 \\
\hline S.Em土 & 0.04 & 0.21 & 0.09 & 0.15 & 0.16 & 0.05 \\
\hline LSD $(P=0.05)$ & 0.11 & 0.62 & 0.28 & 0.45 & 0.47 & 0.14 \\
\hline \multicolumn{7}{|l|}{ Interaction } \\
\hline S.Em+ & 0.08 & 0.41 & 0.19 & 0.30 & 0.31 & 0.09 \\
\hline LSD $(P=0.05)$ & 0.23 & 1.24 & 0.57 & 0.91 & 0.94 & 0.28 \\
\hline
\end{tabular}

Table.3 Effect of nutrient management practices and bio formulations on Yield and economics of groundnut

\begin{tabular}{|c|c|c|c|c|}
\hline Treatment & $\begin{array}{l}\text { Pod yield } \\
\text { (kg/ha) }\end{array}$ & $\begin{array}{l}\text { Haulm yield } \\
\text { (kg/ha) }\end{array}$ & $\begin{array}{c}\text { Gross returns } \\
\text { (Rs/ha) }\end{array}$ & $\mathrm{B}: \mathrm{C}$ \\
\hline \multicolumn{5}{|l|}{ Main Plots: Fertility levels } \\
\hline$F_{1}: 25 \%$ RDF & 1800 & 5746 & 80979 & 1.38 \\
\hline $\mathrm{F}_{2}: \mathbf{5 0 \%} \mathrm{RDF}$ & 1980 & 6049 & 89103 & 1.54 \\
\hline $\mathrm{F}_{3}: 75 \% \mathrm{RDF}$ & 2080 & 6962 & 93579 & 1.60 \\
\hline $\mathrm{F}_{4}: 100 \% \mathrm{RDF}$ & 2258 & 7006 & 101629 & 1.74 \\
\hline S.Em \pm & 39.6 & 262.4 & 1780.3 & 0.051 \\
\hline LSD $(P=0.05)$ & 136.9 & 907.9 & 6160.7 & 0.176 \\
\hline \multicolumn{5}{|l|}{ Sub Plots: Bioformulations } \\
\hline$B_{1}$ : No Bio-formulations & 1946 & 6080 & 87556 & 1.46 \\
\hline $\begin{array}{l}\mathbf{B}_{2}: \text { NPK liquid formulation }+ \\
\text { Zn solubilizing bacteria }\end{array}$ & 2114 & 6676 & 95115 & 1.67 \\
\hline $\mathbf{B}_{3}$ : Bio-grow & 2029 & 6566 & 91297 & 1.56 \\
\hline S.Em五 & 24.3 & 140.6 & 1093.4 & 0.030 \\
\hline LSD $(P=0.05)$ & 72.8 & 421.7 & 3278.1 & 0.091 \\
\hline \multicolumn{5}{|l|}{ Interaction } \\
\hline S.Em+ & 48.6 & 281.3 & 2186.9 & 0.061 \\
\hline LSD $(P=0.05)$ & 145.7 & 843.3 & 6556.2 & 0.182 \\
\hline
\end{tabular}


Multistrain biofertlizer application improved vegetative growth and nodulation which favourably influenced the flowering and fruiting and hence ultimately resulted in increased pod and haulm yield. These findings are in agreement with the results obtained by Chaudhary et al., (2015), Madhu Bala and Kedar Nath (2015).

Significantly highest pod $(2258 \mathrm{~kg} / \mathrm{ha})$ and haulm $(7006 \mathrm{~kg} / \mathrm{ha})$ yield of groundnut was recorded with the application of $100 \% \mathrm{RDF}$ whereas application of $25 \%$ RDF gave the lowest values. Increase in pod and haulm yields was the result of balanced nutrition and favourable soil environment which promoted better assimilation leading to profuse growth and ultimately better yield of crop. This might be due to application of NPK fertilizer along with biofertilizers helped in slow and steady rate of nutrient release into soil solution to match the required absorption pattern of groundnut thereby increase yield. These results are in close conformity with those reported by of Madhu Bala and Kedar Nath, (2015) and Rahevar et al., (2015).

In present investigation, liquid biofertilizers proved to be an important component of integrated nutrient management which showed significant effect on both pod and haulm yield of groundnut. The integrated application of $100 \%$ RDF with liquid NPK formulation $+\mathrm{Zn}$ solubilizing bacteria gave highest pod and haulm yield followed by $100 \%$ RDF application with bio-grow.

This increase in values may be attributed to the the synergistic effect of inorganic and liquid biofertilizers which improved the soil environment resulting in better water absorption, nutrients uptake and overall development of plant leading to higher photosynthetic activity which ultimately resulted in higher pod and haulm yield. The present findings are in close agreement with the results obtained by Patil et al., (2014) and Rahevar et al., (2015).

\section{Economics}

Highest gross realization $(95,115$ '/ha) and benefit cost ratio (1.67) was secured with the treatment $\mathrm{B}_{2}$ (liquid NPK formulation $+\mathrm{Zn}$ solubilizing bacteria) gave but for gross realization this treatment was statistically at par with bio-grow (91297 '/ha). Similarly, the treatment with application of $100 \%$ RDF secured significantly highest gross realization (101629 \%/ha) and benefit cost ratio (1.74) followed by $75 \%$ RDF application which might be due to the highest pod yield.

From the present investigation it can be concluded that inoculation of liquid NPK formulation $+\mathrm{Zn}$ solubilizing bacteria with $100 \%$ recommended dose of NPK brought significant improvement in physiological traits, quality as well as productivity and profitability of groundnut crop.

\section{Acknowledgements}

The Authors wish to thank the Directorate of Groundnut Research (DGR), Junagadh, Gujarat for their financial and laboratory support and Rajmata Vijyaraje Scindia Krishi Vishva Vidhyalaya staffs for their technical assistance.

\section{References}

Aduloju, M.O., Mahmood, J., Abayomi, Y.A. 2009. Evaluation of soybean (Glycine $\max$ L.) genotypes for adaptability to Southern Guinnea Savanna environment with and without $\mathrm{P}$ fertilizer application in north Central Nigeria. Afr. J. Agric. Res. 4: 556-563.

Afifi, M.H.M., Khalifa, R.K. M. and ElDewiny, C.Y. 2011. Urea foliar application as a partial substitution of soil applied nitrogen fertilization for some maize cultivars grown in newly cultivated soil. Australian J. Basic \& Appl. Sci. 5(7): 826-832.

Chaudhary, J.H., Sutaliya, Ramdev and Desai, L. J. 2015. Growth, yield, yield attributes and economics of summer groundnut 
(Arachis hypogaea L.) as influenced by integrated nutrient management. Journal of Applied and Natural Science 7(1): 369372.

Dutta, J.K., Ghosh, A., Banerjee, A., Mondal, N.K. 2012. Biochemical response of selected plant species under air pollution stress. Ecol. Environ. Conserv 18: 957962.

Gomez, K.A. and Gomez, A.A. 1984. Statistical procedure for agricultural research. Second Edition John Willy and Sons Inc., New York.

Gorttappeh, A.H., Ghalavand, A., AhmadY, M.R., Mirnia, S.K. 2000. Effect of organic, inorganic and integrated fertilizer on qualitative and quantitative traits of different cultivars of sunflower (Helianthus annus L.) in Western Azerbaijan. Iran J. Agric. Sci. 6: 85-104.

Hegde, D.M. and Sudhakara Babu, S.N. 2009. Declining factor productivity and improving nutrient use efficiency in oilseeds. Indian J. Agron. 54 (1):1-8.

Madhu Bala and Kedar Nath. 2015. Maximization of groundnut (Arachis hypogaea L.) yield by nutrient management practices. Journal of Experimental Biology and Agricultural Sciences 3(3): 241-245.

Mahasen, S.A.S., Zaghlour, R.A. and ElGhozoli, M.A. 2002. Effectiveness of dual inoculation with Brady rhizobium and endomycorrhizae in presence of different phosphtic fertilizer sources on growth and yield of soybean. Ann. Agril. Sci. 47: 477-500.

More, K.A., Gaikwad, C.B., Dahat, D.V. 2002. Effect of N, P, Rhizobium and phosphate solublizing bacteria on groundnut. J. Maharashtra Agrll. Univ. 27: 202-204.

Nadaf, S.A., Chidanandappa, H.M. and Yadahalli, V. 2013. Research Journal of Agricultural Sciences 4(2): 196-198.

Patil, S. R., Kadam, S. R., Kalegore, N.K. and Dadgale, P. R. 2014. Effect of inorganic and bio-fertilizers on growth and yield of summer groundnut. Advance Research Journal of Crop Improvement 5(1): 23-25.

Phan Thi Cong, Tran Dang Dung, Nguyen Thanh Hien, Abu, T., Choudhury, M. A., Michael T. Rose, Mihály L. Kecskés, Rosalind Deaker and Ivan R. Kennedy 2011. Effects of a multistrain biofertilizer and phosphorus rates on nutrition and grain yield of paddy rice on a sandy soil in Southern Vietnam. Journal of Plant Nutrition 34: 1058-1069.

Rahevar, H.D., Patel, P.P., Patel, B.T., Joshi, S.K. and Vaghela, S.J. 2015. Effect of FYM, iron and zinc on growth and yield of summer groundnut (Arachis hypogaea L.) under North Gujarat Agro-climatic conditions. Indian Journal Agricultural Research 49(3): 294-296.

Singh, G.P., Singh, P.L. and Panwar, A.S. 2011. Response of groundnut (Arachis hypogaea L.) to biofertilizers, organic and inorganic sources of nutrient in NorthEast India. Legume Research 34:196-201.

Vala, F.G., Vaghasia, P.M., Zala, K.P. and Buha, D.B. 2017. Effect of Integrated Nutrient Management on Productivity of Summer Groundnut (Arachis hypogaea L.). International Journal of Current Microbiology and Applied Sciences 6(10): 1951-1957.

\section{How to cite this article:}

Neelam Singh, Ekta Joshi, D.S. Sasode, R.S. Sikarwar and Rawat, G.S. 2018. Liquid Biofertilizer and Inorganic Nutrients Effect on Physiological, Quality Parameters and Productivity of Kharif Groundnut (Arachis hypogaea L.). Int.J.Curr.Microbiol.App.Sci. 7(09): 729-735. doi: https://doi.org/10.20546/ijcmas.2018.709.087 